\title{
Export Performance and Economic Growth in East Asian Economies - Application of Cointegration and Vector Error Correction Model
}

\author{
Neena MALHOTRA ${ }^{*}$, Deepika KUMARI ${ }^{* *}$
}

\begin{abstract}
East Asian Economies are considered to be most successful economies in the world. Following the footsteps of other East Asian economies such as Japan and South Korea, China also shifted towards export-led growth strategy in 80s. This study analyzes the effect of export performance on economic growth of three major East Asian economies i.e. Japan, South Korea, and China. This study has conducted the econometric analysis of macro data under multivariate framework for the period 1980-2012. In order to examine the causal relationship between exports and economic growth, the study has applied time series techniques such as Augmented Dickey-Fuller (ADF) and PhillipsPerron (PP) unit root tests to check stationarity of variables, Johansen cointegration test for long run relationship, vector error correction model (VECM) for short run dynamics and for estimating speed of adjustment towards long run equilibrium. The analysis also made use of techniques Impulse Response Function (IRF) and Variance Decomposition Analysis (VDA) to investigate the interrelationships within the system. The estimated results suggested that all variables were cointegrated for East Asian economies. The study concluded that export-led growth (ELG) was only long run phenomenon in China and South Korea. The results for Japan supported growth led exports (GLE) particularly for short run.
\end{abstract}

Keywords: Export-led Growth, Southeast Asia, time series, cointegration, VECM, impulse response function, variance decomposition analysis

JEL Code Classification: C12, C32, F14, F43

UDC: 339.564(5-12):330.35

DOI: https://doi.org/10.17015/ejbe.2016.018.08

\footnotetext{
* Corresponding author. Associate Professor, Punjab School of Economics, Guru Nanak Dev University, Punjab, India. E-mail: malhotradrneena@gmail.com.

** Senior Research Fellow, Punjab School of Economics, Guru Nanak Dev University, Punjab, India.

E-mail: deepikaeco.rsh@gndu.ac.in.
} 


\section{Introduction and Background}

After Second World War, Japan focused on industrialization and expansion of exports which led to rapid economic growth of the economy. Later on, Japan's export-led growth model was adopted by four Asian tigers or first tier of newly industrialized economies (NIEs) namely Hong Kong, South Korea, Singapore and Taiwan in the 1960s. After the success of four Asian tigers since 1970, second tier of newly industrialized economies (NIEs) of Southeast Asia namely Indonesia, Malaysia, Thailand and Philippines replicated this strategy. Finally China and India gradually followed this strategy. Hence, rapidly growing economies of Asian region have widely followed export-led growth strategy as an effective tool for development (Page, 1994; Kokko, 2002; Chow, 2012).

East Asia is considered as most successful sub region of Asia. China is the largest country in terms of geographic and demographic features. China's population is ten times more than Japan's population and twenty seven times that of South Korea. Japan and South Korea are located just off the coast of mainland China. In 2012, China, Japan and South Korea together constituted about 20 percent of world economic output in nominal terms. Moreover, China was also the largest trading partner of both Japan and South Korea in the same year. Industrialization was the main reason behind the economic development of these economies (Berglee, 2012; O’Reilly, 2012; Park \& Patrick, 2013).

The compound growth rates of exports, imports and trade for East Asian economies have been reported in Table 1. Table indicates remarkable exports performance of China and South Korea during 1981-2012. However, Japan's export performance was low during 80 s and further declined during later decades. In case of GDP, only China was able to secure double digit growth throughout the study period. Growth rates of exports and GDP are relatively lower for Japan, which is due to Japan being a mature developed economy as well as slowdown in developed world.

Table 1. Growth performance of East Asian Economies (Compound Growth Rates)

\begin{tabular}{cccccccccc}
\hline & \multicolumn{3}{c}{ China } & \multicolumn{3}{c}{ Japan } & \multicolumn{3}{c}{ South Korea } \\
\hline Year & Export & Import & GDP & Export & Import & GDP & Export & Import & GDP \\
\hline $1981-1990$ & 14.14 & 19.70 & 10.46 & 4.47 & 6.74 & 4.72 & 11.67 & 11.93 & 9.18 \\
$1991-2000$ & 22.01 & 22.05 & 10.42 & 4.30 & 4.69 & 0.92 & 16.44 & 9.50 & 5.46 \\
$2001-2012$ & 13.03 & 11.08 & 10.73 & 4.23 & 2.04 & 0.67 & 10.56 & 8.47 & 3.86 \\
$1980-2012$ & 18.73 & 18.52 & 10.02 & 4.64 & 4.36 & 1.93 & 12.34 & 10.33 & 6.15 \\
\hline
\end{tabular}

Source: Calculations based on data from World Development Indicators (WDI), online database.

The purpose of this study is to empirically investigate export-growth relationship for major East Asian economies namely China, Japan and South Korea by using time series data analysis including structural breaks under multivariate framework. The methodology used in this study is little improvement over previous studies as it 
includes structural breaks, diagnostic tests and forecasting methods such as impulse response function (IRF) and variance decomposition analysis (VDA). The first section includes introductory part and brief background of East Asian economies. The next section reports review of literature. Further, methodology and empirical results have been given. Final section presents conclusions and also contains comparison of our results with previous studies.

\section{Review of Literature}

The literature reviewed indicates that comprehensive studies based on rigorous statistical analysis comprising forecasting methods and identifying structural breaks are lacking (Table 2). Therefore, the present study has made an attempt to analyze the relationship between exports and economic growth by adopting above mentioned methods. The evidence for export-led growth hypothesis is inconclusive as the results provided by these studies are not unanimous. Hence, in the light of above facts, the study takes into account these issues in further investigation.

Table 2. A Brief Review of the Related Economic Literature on East Asia

\begin{tabular}{|c|c|c|c|c|c|}
\hline Author & $\begin{array}{l}\text { Period of the } \\
\text { study }\end{array}$ & $\begin{array}{l}\text { Countries } \\
\text { / Region }\end{array}$ & $\begin{array}{l}\text { Objective of the } \\
\text { study }\end{array}$ & Methodology & Conclusions* \\
\hline $\begin{array}{l}\text { Fawson } \\
\text { and } \\
\text { Chang } \\
\text { (1994) }\end{array}$ & $\begin{array}{l}\text { Japan (1970-92), } \\
\text { Philippines (1983- } \\
\text { 93), South Korea } \\
\text { (1971-92), } \\
\text { Taiwan, } \\
\text { UK (1970-92), USA } \\
(1970-92)\end{array}$ & $\begin{array}{l}\text { Japan, } \\
\text { Philippine } \\
\text { s, South } \\
\text { Korea, } \\
\text { Taiwan, } \\
\text { UK, USA } \\
\end{array}$ & $\begin{array}{l}\text { Examined the } \\
\text { causal } \\
\text { relationship } \\
\text { between exports } \\
\text { and growth }\end{array}$ & $\begin{array}{l}\text { Hsiao's Granger } \\
\text { Causality Test }\end{array}$ & $\begin{array}{l}\text { ELG- Philippines } \\
\text { GLE- South Korea, } \\
\text { Japan and United } \\
\text { States } \\
\text { BDC- Taiwan and } \\
\text { United Kingdom }\end{array}$ \\
\hline $\begin{array}{l}\text { Holman } \\
\text { and } \\
\text { Graves } \\
(1995) \\
\end{array}$ & $1953-90$ & $\begin{array}{l}\text { South } \\
\text { Korea }\end{array}$ & $\begin{array}{l}\text { Analyzed the role } \\
\text { of exports in } \\
\text { stimulating } \\
\text { exports }\end{array}$ & $\begin{array}{l}\text { Sim's Test and } \\
\text { Granger Causality } \\
\text { Test }\end{array}$ & $\begin{array}{l}\text { Both tests } \\
\text { supported two way } \\
\text { causation }\end{array}$ \\
\hline $\begin{array}{l}\text { Kwan } \\
\text { and } \\
\text { Kwok } \\
(1995) \\
\end{array}$ & $1952-85$ & China & $\begin{array}{l}\text { Examined the } \\
\text { validity of export- } \\
\text { led growth } \\
\text { hypothesis }\end{array}$ & Granger Causality & $\begin{array}{l}\text { Supported the } \\
\text { validity of export- } \\
\text { led growth } \\
\text { hypothesis }\end{array}$ \\
\hline $\begin{array}{l}\text { Boltho } \\
\text { (1996) }\end{array}$ & $\begin{array}{l}\text { Three periods } \\
(1913-37,1952- \\
73,1973-90) \\
\end{array}$ & Japan & $\begin{array}{l}\text { Investigated } \\
\text { export-led growth } \\
\text { hypothesis }\end{array}$ & Granger Causality & $\begin{array}{l}\text { Findings didn't } \\
\text { favour export led } \\
\text { growth hypothesis }\end{array}$ \\
\hline $\begin{array}{l}\text { Liu, Song } \\
\text { and } \\
\text { Romilly } \\
\text { (1997) }\end{array}$ & 1983-95 & China & $\begin{array}{l}\text { Examined causal } \\
\text { relationship } \\
\text { between } \\
\text { economic growth } \\
\text { and exports + } \\
\text { imports }\end{array}$ & $\begin{array}{l}\text { ADF unit root, } \\
\text { cointegration } \\
\text { test, Causality } \\
\text { test based on } \\
\text { Granger (1969), } \\
\text { Sims (1969), } \\
\text { Geweke et al. } \\
\text { (1983) and Hsiao } \\
\text { (1981) models }\end{array}$ & $\begin{array}{l}\text { Feedback causal } \\
\text { relationship was } \\
\text { confirmed. }\end{array}$ \\
\hline
\end{tabular}


Table 2 (cont.) A Brief Review of the Related Economic Literature on East Asia

\begin{tabular}{|c|c|c|c|c|c|}
\hline Author & $\begin{array}{l}\text { Period of the } \\
\text { study }\end{array}$ & $\begin{array}{l}\text { Countries } \\
\text { / Region }\end{array}$ & $\begin{array}{l}\text { Objective of the } \\
\text { study }\end{array}$ & Methodology & Conclusions* \\
\hline $\begin{array}{l}\text { Shan and } \\
\text { Sun } \\
(1998)\end{array}$ & $1987-96$ & China & $\begin{array}{l}\text { Examined the } \\
\text { causality link } \\
\text { between exports } \\
\text { and economic } \\
\text { growth }\end{array}$ & $\begin{array}{l}\text { Unit Root and } \\
\text { Causality test } \\
\text { developed by } \\
\text { Toda-Yamamoto } \\
\text { (1995) }\end{array}$ & $\begin{array}{l}\text { Bidirectional } \\
\text { Causality between } \\
\text { exports and real } \\
\text { industrial output. }\end{array}$ \\
\hline $\begin{array}{l}\operatorname{Lin} \\
\text { (1999) }\end{array}$ & 1978-1995 & China & $\begin{array}{l}\text { Examined the } \\
\text { effects of exports } \\
\text { on economic } \\
\text { growth }\end{array}$ & Regression & $\begin{array}{l}\text { Positive relationship } \\
\text { was found between } \\
\text { growth rate of } \\
\text { exports and growth } \\
\text { rate of per capita } \\
\text { GDP }\end{array}$ \\
\hline $\begin{array}{l}\text { Hatemi-J } \\
(2002)\end{array}$ & 1960-1999 & Japan & $\begin{array}{l}\text { Investigated causal } \\
\text { relationship } \\
\text { between exports } \\
\text { and economic } \\
\text { growth }\end{array}$ & $\begin{array}{l}\text { Granger causality } \\
\text { test using } \\
\text { bootstrap } \\
\text { simulation } \\
\text { technique }\end{array}$ & $\begin{array}{l}\text { Bidirectional } \\
\text { causality was } \\
\text { observed between } \\
\text { exports and output }\end{array}$ \\
\hline $\begin{array}{l}\text { Liu, } \\
\text { Burridge } \\
\text { and } \\
\text { Sinclair } \\
\text { (2002) }\end{array}$ & 1981-1997 & China & $\begin{array}{l}\text { Investigated the } \\
\text { causal link between } \\
\text { trade, economic } \\
\text { growth and inward } \\
\text { FDI }\end{array}$ & $\begin{array}{l}\text { ADF, } \\
\text { Cointegration and } \\
\text { Causality }\end{array}$ & $\begin{array}{l}\text { Identified long run } \\
\text { relationship } \\
\text { between these } \\
\text { variables. Two- way } \\
\text { causal connect was } \\
\text { found between } \\
\text { economic growth } \\
\text { and FDI, Exports. }\end{array}$ \\
\hline $\begin{array}{l}\text { Awokuse } \\
\text { (2005) }\end{array}$ & $\begin{array}{l}1960-I \text { to } 1991- \\
\text { IV }\end{array}$ & Japan & $\begin{array}{l}\text { Explored the causal } \\
\text { relationship } \\
\text { between real } \\
\text { exports and GDP }\end{array}$ & $\begin{array}{l}\text { Toda-Yamamoto } \\
\text { approach, } \\
\text { directed acyclic } \\
\text { graphs (DAG), and } \\
\text { forecast error } \\
\text { variance } \\
\text { decompositions } \\
\text { (FEVD) }\end{array}$ & $\begin{array}{l}\text { The study } \\
\text { confirmed } \\
\text { bidirectional } \\
\text { causality in case of } \\
\text { Japan. }\end{array}$ \\
\hline $\begin{array}{l}\text { Awokuse } \\
\text { (2005) }\end{array}$ & $\begin{array}{l}\text { 1963:I to } \\
2001: I V\end{array}$ & Korea & $\begin{array}{l}\text { Examined the } \\
\text { export-led growth } \\
\text { (ELG) hypothesis } \\
\text { for Korea }\end{array}$ & $\begin{array}{l}\text { Johansen } \\
\text { Cointegration Test } \\
\text { and Vector Error } \\
\text { Correction Model } \\
\text { (VECM) and Toda- } \\
\text { Yamamoto } \\
\text { approach }\end{array}$ & $\begin{array}{l}\text { The study found } \\
\text { feedback } \\
\text { relationship } \\
\text { between exports } \\
\text { and growth and } \\
\text { supported } \\
\text { ELG hypothesis. }\end{array}$ \\
\hline $\begin{array}{c}\text { Yao } \\
(2006)\end{array}$ & $1978-2000$ & China & $\begin{array}{l}\text { Examined the } \\
\text { hypothesis both } \\
\text { exports and FDI } \\
\text { have positive effect } \\
\text { on economic } \\
\text { growth }\end{array}$ & $\begin{array}{l}\text { Panel unit root \& } \\
\text { Dynamic Panel } \\
\text { Data (DPD) } \\
\text { estimation }\end{array}$ & $\begin{array}{l}\text { Found strong and } \\
\text { positive effect of } \\
\text { Exports and FDI on } \\
\text { economic growth }\end{array}$ \\
\hline
\end{tabular}


Export Performance and Economic Growth in East Asian Economies -Application of ...

Table 2 (cont.) A Brief Review of the Related Economic Literature on East Asia

\begin{tabular}{|c|c|c|c|c|c|}
\hline Author & $\begin{array}{l}\text { Period of the } \\
\text { study }\end{array}$ & $\begin{array}{l}\text { Countries/ } \\
\text { Region }\end{array}$ & $\begin{array}{l}\text { Objective of the } \\
\text { study }\end{array}$ & Methodology & Conclusions* \\
\hline $\begin{array}{l}\text { Mah } \\
\text { (2007) }\end{array}$ & 1980-2001 & China & $\begin{array}{l}\text { Examined the } \\
\text { causality among } \\
\text { economic } \\
\text { growth, export } \\
\text { expansion and } \\
\text { export } \\
\text { composition }\end{array}$ & $\begin{array}{l}\text { Johansen } \\
\text { Cointegration Test } \\
\text { and Error } \\
\text { Correction Model } \\
\text { (ECM) }\end{array}$ & $\begin{array}{l}\text { Didn't find } \\
\text { cointegration } \\
\text { among } \\
\text { variables. } \\
\text { However, ECM } \\
\text { confirmed } \\
\text { bidirectional } \\
\text { causality }\end{array}$ \\
\hline $\begin{array}{c}\text { Ding and } \\
\text { Knight } \\
(2008)\end{array}$ & 1978-2006 & China & $\begin{array}{l}\text { Explore the } \\
\text { reason for } \\
\text { China's growth } \\
\text { success } \\
\text { including degree } \\
\text { of openness, } \\
\text { institutional } \\
\text { change and } \\
\text { sectoral change }\end{array}$ & Regression & $\begin{array}{l}\text { All the three } \\
\text { were found to } \\
\text { be important to } \\
\text { raise the growth } \\
\text { rate of China }\end{array}$ \\
\hline
\end{tabular}

The uncertainty results revealed GDP growth was import led in

\begin{tabular}{|c|c|c|c|c|c|}
\hline $\begin{array}{c}\text { Mahade } \\
\text { van and } \\
\text { Suardi } \\
(2008)\end{array}$ & $\begin{array}{l}\text { Up to } 2005 \\
\text { (more than } 30 \\
\text { years) }\end{array}$ & $\begin{array}{l}\text { Japan, Korea, } \\
\text { Taiwan \& } \\
\text { Hong-Kong }\end{array}$ & $\begin{array}{l}\text { Examined the } \\
\text { stability of } \\
\text { trade-growth } \\
\text { nexus by } \\
\text { incorporating } \\
\text { the effects of } \\
\text { uncertainty or } \\
\text { volatility }\end{array}$ & $\begin{array}{l}\text { ADF, KPSS tests for } \\
\text { unit root, } \\
\text { Cointegration, } \\
\text { VECM }\end{array}$ & $\begin{array}{l}\text { Japan, both } \\
\text { export \& import } \\
\text { led in Hong- } \\
\text { Kong, mutually } \\
\text { causative in } \\
\text { Taiwan. No } \\
\text { causation from } \\
\text { GDP growth to } \\
\text { exports and } \\
\text { imports was } \\
\text { observed for } \\
\text { Korea (vice } \\
\text { versa). }\end{array}$ \\
\hline $\begin{array}{l}\text { Herreria } \\
\text { s and } \\
\text { Orts } \\
(2010)\end{array}$ & 1964-2004 & China & $\begin{array}{l}\text { Analyzed } \\
\text { whether growth } \\
\text { is export- led or } \\
\text { investment- led }\end{array}$ & ADF, VECM & $\begin{array}{l}\text { Found evidence } \\
\text { for both }\end{array}$ \\
\hline $\begin{array}{l}\text { Sun and } \\
\text { Heshmat } \\
\text { i (2010) }\end{array}$ & $2002-2007$ & China & $\begin{array}{l}\text { Evaluated the } \\
\text { effect of } \\
\text { international } \\
\text { trade on } \\
\text { economic } \\
\text { growth }\end{array}$ & $\begin{array}{l}\text { Likelihood Ratio } \\
\text { Test, One Way } \\
\text { ANOVA, Non } \\
\text { Parametric Test }\end{array}$ & $\begin{array}{l}\text { Positive } \\
\text { relationship was } \\
\text { found between } \\
\text { international } \\
\text { trade and } \\
\text { economic } \\
\text { growth }\end{array}$ \\
\hline
\end{tabular}


Table 2 (cont.) A Brief Review of the Related Economic Literature on East Asia

\begin{tabular}{|c|c|c|c|c|c|}
\hline Author & $\begin{array}{l}\text { Period of the } \\
\text { study }\end{array}$ & $\begin{array}{l}\text { Countries } \\
\text { / Region }\end{array}$ & $\begin{array}{l}\text { Objective of the } \\
\text { study }\end{array}$ & Methodology & Conclusions* \\
\hline $\begin{array}{l}\text { Tsen } \\
(2010)\end{array}$ & $1978-2002$ & China & $\begin{array}{l}\text { Examined } \\
\text { causality among } \\
\text { exports, domestic } \\
\text { demand and } \\
\text { economic growth }\end{array}$ & $\begin{array}{l}\text { ER and PP test } \\
\text { for Unit root, } \\
\text { Bound testing } \\
\text { approach }\end{array}$ & $\begin{array}{l}\text { Bidirectional } \\
\text { causality, evidence of } \\
\text { export-led growth, } \\
\text { growth led exports, } \\
\text { domestic demand led } \\
\text { growth and growth } \\
\text { led domestic demand }\end{array}$ \\
\hline $\begin{array}{l}\text { Marelli } \\
\text { and } \\
\text { Signorelli } \\
\text { (2011) }\end{array}$ & $1980-2007$ & China & $\begin{array}{l}\text { Estimated the link } \\
\text { between } \\
\text { openness and } \\
\text { growth of China } \\
\text { and India }\end{array}$ & $\begin{array}{l}\text { 2SLS (Panel } \\
\text { Data) }\end{array}$ & $\begin{array}{l}\text { Positive growth } \\
\text { effects after opening } \\
\text { up. }\end{array}$ \\
\hline $\begin{array}{l}\text { Yin and } \\
\text { Hamori } \\
(2012)\end{array}$ & 1970-2009 & China & $\begin{array}{l}\text { Compared the } \\
\text { impact of } \\
\text { openness on } \\
\text { growth of China } \\
\text { and India }\end{array}$ & $\begin{array}{l}\text { ADF, FMOLS, } \\
\text { DOLS }\end{array}$ & $\begin{array}{l}\text { Increasing openness } \\
\text { has greater impact on } \\
\text { the growth of China } \\
\text { as compare to India }\end{array}$ \\
\hline $\begin{array}{l}\text { Zhang } \\
\text { and } \\
\text { Baimbrid } \\
\text { ge } \\
(2011)\end{array}$ & $\begin{array}{l}\text { South Korea } \\
\text { (1963-2003), } \\
\text { Japan (1957- } \\
\text { 2003) }\end{array}$ & $\begin{array}{l}\text { South } \\
\text { Korea, } \\
\text { Japan }\end{array}$ & $\begin{array}{l}\text { Investigated the } \\
\text { relationship } \\
\text { between exports, } \\
\text { imports and } \\
\text { economic growth }\end{array}$ & $\begin{array}{l}\text { ADF, Johansen } \\
\text { Cointegration } \\
\text { and VECM }\end{array}$ & $\begin{array}{l}\text { Negative effect from } \\
\text { Real GDP to real } \\
\text { exports in case of } \\
\text { South Korea while } \\
\text { ELG was found for } \\
\text { Japan }\end{array}$ \\
\hline $\begin{array}{l}\text { Kumari } \\
\text { and } \\
\text { Malhotr } \\
\text { a (2014) }\end{array}$ & $1980-2012$ & China & $\begin{array}{l}\text { Analyzed trade- } \\
\text { led growth } \\
\text { hypothesis for } \\
\text { India and China }\end{array}$ & $\begin{array}{l}\text { ADF,PP, } \\
\text { Johansen } \\
\text { Cointegration } \\
\text { and Toda- } \\
\text { Yamamoto } \\
\text { Approach }\end{array}$ & $\begin{array}{l}\text { Trade-led Growth } \\
\text { hypothesis was found } \\
\text { valid for China. In case } \\
\text { of India only } \\
\text { unidirectional } \\
\text { causality running from } \\
\text { GDP to exports i.e. } \\
\text { growth-led exports } \\
\text { was confirmed. }\end{array}$ \\
\hline
\end{tabular}

*Note: BDC refers to bi-directional causality, ELG refers to export led growth, GLE refers to growth led export.

\section{Model, Database and Econometric Strategy}

The aggregate production function used in the study can be expressed as:

$$
Y=f(K, L, X, M)
$$

Where $Y$ represents real gross domestic product and $K, L, X, M$ represent capital, labour, exports and imports respectively. This model has been used to examine the 
Export Performance and Economic Growth in East Asian Economies -Application of ...

export-led growth (ELG) hypothesis for major East Asian economies. The study has used annual data at the 2005 constant US dollar prices from 1980 to 2012. Data on real GDP per capita(GDPPC), real exports(EXP), real imports(IMP), real gross capital formation(GCF) has been compiled from World Development Indicators (WDI) online database, World Bank, while data on total labour force(LAB) is collected from United Nation Conference on Trade and Development (UNCTAD) Statistics.

All the variables are taken in their natural logarithms to avoid the problem of heteroskedasticity (Gujarati 1995).For the application of multivariate econometric techniques, the above stated model can be expressed in the following linear logarithmic form:

$L N G D P P C_{t}=\beta_{0}+\beta_{1} L N E X P_{t}+\beta_{2} L N I M P_{t}+\beta_{3} L N G C F_{t}+\beta_{4} L N L A B_{t}+\varepsilon_{t}$

The prefix 'LN' stands for natural logarithm. The study takes into account dummies for Asian Financial Crisis (1997) and Global Economic Crisis (2008). To examine the export-led growth hypothesis cointegration and VECM based causality tests have been used.

\section{Estimates of Multivariate Analysis}

\subsection{Unit Root Results}

The results in Table 3 give the summary of ADF and PP tests for East Asian economies.

\section{Table 3. Results of Unit Root test for variables}

\begin{tabular}{|c|c|c|c|c|c|c|c|c|c|}
\hline \multirow{2}{*}{$\begin{array}{l}\text { Count- } \\
\text { ries }\end{array}$} & \multirow{2}{*}{ Variables } & \multicolumn{3}{|c|}{ ADF (Test Statistics) } & \multirow{2}{*}{$\begin{array}{c}\text { Order of } \\
\text { Integra- } \\
\text { tion }\end{array}$} & \multicolumn{3}{|c|}{ PP (Test Statistic) } & \multirow{2}{*}{$\begin{array}{l}\text { Order of } \\
\text { Integra- } \\
\text { tion }\end{array}$} \\
\hline & & Level & $\begin{array}{c}\text { First } \\
\text { Difference }\end{array}$ & $\begin{array}{c}\text { Second } \\
\text { Difference }\end{array}$ & & Level & $\begin{array}{c}\text { First } \\
\text { Difference }\end{array}$ & $\begin{array}{c}\text { Second } \\
\text { Difference }\end{array}$ & \\
\hline \multirow{5}{*}{ China } & LNGDPPC & -2.974 & $-4.258 * *$ & - & $\mathrm{I}(1)$ & -2.215 & $-3.255^{* * *}$ & - & $\mathrm{I}(1)$ \\
\hline & LNEXP & -1.483 & $-5.378^{*}$ & - & $\mathrm{I}(1)$ & -1.587 & $-5.378 *$ & - & $\mathrm{I}(1)$ \\
\hline & LNIMP & 0.394 & $-3.942 * *$ & - & $I(1)$ & -1.444 & $-3.942 * *$ & - & $\mathrm{I}(1)$ \\
\hline & LNGCF & $-3.960 * *$ & - & - & $I(0)$ & -2.547 & $-3.922 * *$ & - & $\mathrm{I}(1)$ \\
\hline & LNDLAB & -2.570 & $-6.371^{*}$ & - & $I(1)$ & -2.570 & $-6.371^{*}$ & - & $\mathrm{I}(1)$ \\
\hline \multirow{5}{*}{ Japan } & LNGDPPC & -1.413 & $-4.893^{*}$ & - & $\mathrm{I}(1)$ & -1.413 & $-4.893^{*}$ & - & $\mathrm{I}(1)$ \\
\hline & LNEXP & -2.328 & $-5.564 *$ & - & $\mathrm{I}(1)$ & -2.416 & $-5.564 *$ & - & $\mathrm{I}(1)$ \\
\hline & LNIMP & -2.154 & $-4.339 *$ & - & $\mathrm{I}(1)$ & -1.822 & $-4.379 *$ & - & $\mathrm{I}(1)$ \\
\hline & LNGCF & -1.153 & $-4.162 * *$ & - & $I(1)$ & -1.241 & $-4.162^{* *}$ & - & $I(1)$ \\
\hline & LNLAB & -1.255 & -3.111 & $-6.287^{*}$ & $I(2)$ & -0.934 & -3.111 & $-6.341^{*}$ & $I(2)$ \\
\hline \multirow{5}{*}{$\begin{array}{l}\text { South } \\
\text { Korea }\end{array}$} & LNGDPPC & -0.623 & $-5.751^{*}$ & - & $I(1)$ & -0.623 & $-5.751^{*}$ & - & $\mathrm{I}(1)$ \\
\hline & LNEXP & -1.516 & $-4.824^{*}$ & - & $I(1)$ & -1.781 & $-4.824^{*}$ & - & $\mathrm{I}(1)$ \\
\hline & LNIMP & -1.630 & $-5.566^{*}$ & - & $\mathrm{I}(1)$ & -1.630 & $-5.786 *$ & - & $\mathrm{I}(1)$ \\
\hline & LNGCF & -1.068 & $-5.673^{*}$ & - & $I(1)$ & -1.068 & $-5.673^{*}$ & - & $\mathrm{I}(1)$ \\
\hline & LNLAB & -0.511 & $-4.806 *$ & - & $\mathrm{I}(1)$ & 0.578 & $-4.806 *$ & - & $\mathrm{I}(1)$ \\
\hline
\end{tabular}

Note: ${ }^{*}, * *$ and $* * *$ indicate significance at the $1 \%, 5 \%$ and $10 \%$ respectively. Values in the parentheses show $\mathrm{p}$-values. 
Augmented Dickey- Fuller (ADF) test and Phillip-Perron (PP) test (including constant with trend) for five variables namely LNGDPPC, LNEXP, LNIMP, LNGCF \&LNLAB have been applied to check whether series are stationary or not. The results revealed the presence of unit root for all series at levels. After differencing, all series were found to be stationary except the series LNLAB for Japan. The variable integrated of order two or I(2) was dropped from the model in case of Japan.

\subsection{Chow Test Results}

Time series plotting of the variables indicated the presence of structural breaks. Hence, Chow breakpoint test has been used to identify and confirm structural break in dataset. This test analyzes the null hypothesis of no structural break.

The results in Table 4 clearly indicate the absence of structural break in dataset as the null hypothesis of no structural break can't be rejected for China. For Japan and South Korea, the results affirmed the presence of structural break in dataset. Asian crisis of 1997 had severe impact on South Korea's economy. The results showed the presence of structural break for Japan and South Korea's dataset for 2008.

Table 4. Results of Chow Breakpoint Test

\begin{tabular}{|c|c|c|c|}
\hline \multicolumn{4}{|l|}{ China } \\
\hline \multicolumn{4}{|c|}{ Chow Breakpoint Test: 2008} \\
\hline \multicolumn{4}{|c|}{ Null Hypothesis: No breaks at specified breakpoints } \\
\hline \multicolumn{4}{|c|}{ Equation Sample: 19812012} \\
\hline F-statistic & 0.230 & Prob.F & 0.945 \\
\hline Log likelihood ratio & 1.634 & Prob. Chi-Square & 0.897 \\
\hline Wald Statistic & 1.152 & Prob. Chi-Square & 0.949 \\
\hline \multicolumn{4}{|l|}{ Japan } \\
\hline \multicolumn{4}{|c|}{ Chow Breakpoint Test: 2008} \\
\hline \multicolumn{4}{|c|}{$\begin{array}{l}\text { Null Hypothesis: No breaks at specified breakpoints } \\
\text { Equation Sample: } 19812012\end{array}$} \\
\hline F-statistic & 2.460 & Prob.F & 0.064 \\
\hline Log likelihood ratio & 14.212 & Prob. Chi-Square & 0.014 \\
\hline Wald Statistic & 12.300 & Prob. Chi-Square & 0.030 \\
\hline \multicolumn{4}{|l|}{ South Korea } \\
\hline \multicolumn{4}{|c|}{ Chow Breakpoint Test: 1997 \& 2008} \\
\hline \multicolumn{4}{|c|}{ Null Hypothesis: No breaks at specified breakpoints } \\
\hline \multicolumn{4}{|c|}{ Equation Sample: 19812012} \\
\hline F-statistic & 10.408 & Prob.F & 0.000 \\
\hline Log likelihood ratio & 39.023 & Prob. Chi-Square & 0.000 \\
\hline Wald Statistic & 52.040 & Prob. Chi-Square & 0.000 \\
\hline F-statistic & 4.637 & Prob.F & 0.004 \\
\hline Log likelihood ratio & 23.007 & Prob. Chi-Square & 0.000 \\
\hline Wald Statistic & 23.187 & Prob. Chi-Square & 0.000 \\
\hline
\end{tabular}


Export Performance and Economic Growth in East Asian Economies -Application of ...

\subsection{VAR Lag Order Selection Criteria}

The next step involves investigation of the long run relationship among variables. Before applying Johansen cointegration procedure appropriate lag length must be set. In Table 5, the results of VAR lag order selection criteria have been presented. Schwarz information criterion was adopted to estimate cointegration and unrestricted VAR.

\section{Table 5. Results of VAR Lag Order Selection Criteria}

\section{China}

Endogenous variables: LNGDPPC LNEXP LNIMP LNGCF LNDLAB

Exogenous variables: C Sample: 19802012

\begin{tabular}{cccccc}
\hline Lag & LR & FPE & AIC & SC & HQ \\
\hline 0 & NA & $2.21 \mathrm{e}-08$ & -3.440 & -3.204 & -3.366 \\
\hline 1 & 235.495 & $4.56 \mathrm{e}-12$ & -11.955 & $-10.541^{*}$ & -11.512 \\
\hline 2 & $40.505^{*}$ & $3.19 \mathrm{e}-12$ & -12.481 & -9.888 & -11.669 \\
\hline 3 & 35.946 & $1.84 \mathrm{e}-12^{*}$ & $-13.522^{*}$ & -9.750 & $-12.341^{*}$ \\
\hline
\end{tabular}

Japan

Endogenous variables: LNGDPPC LNEXP LNIMP LNGCF

Exogenous variables: C DUMMY Sample: 19802012

\begin{tabular}{cccccc}
\hline Lag & LR & FPE & AIC & SC & HQ \\
\hline 0 & NA & $1.51 \mathrm{e}-08$ & -6.656 & -6.467 & -6.596 \\
\hline 1 & 249.127 & $1.43 \mathrm{e}-12$ & -15.932 & $-14.989^{*}$ & -15.637 \\
\hline 2 & $27.590^{*}$ & $1.17 \mathrm{e}-12^{*}$ & $-16.208^{*}$ & -14.511 & $-15.677^{*}$ \\
\hline 3 & 9.649 & $2.33 \mathrm{e}-12$ & -15.708 & -13.256 & -14.940 \\
\hline 4 & 16.891 & $2.59 \mathrm{e}-12$ & -16.012 & -12.806 & -15.008 \\
\hline
\end{tabular}

\section{South Korea}

Endogenous variables: LNGDPPC LNEXP LNIMP LNGCF LNLAB

Exogenous variables: C DUMMY1 DUMMY2 Sample: 19802012

\begin{tabular}{cccccc}
\hline Lag & LR & FPE & AIC & SC & HQ \\
\hline 0 & NA & $1.09 \mathrm{e}-13$ & -15.659 & -14.959 & -15.435 \\
\hline 1 & 192.166 & $9.90 \mathrm{e}-17$ & -22.727 & $-20.859^{*}$ & -22.130 \\
\hline 2 & $38.459^{*}$ & $6.94 \mathrm{e}-17$ & -23.323 & -20.287 & -22.352 \\
\hline 3 & 27.603 & $6.88 \mathrm{e}-17^{*}$ & $-23.957^{*}$ & -19.753 & $-22.612^{*}$ \\
\hline
\end{tabular}

* indicates lag order selected by the criterion

LR: sequential modified LR test statistic (each test at $5 \%$ level)

FPE: Final prediction error

AIC: Akaike information criterion

SC: Schwarz information criterion

HQ: Hannan-Quinn information criterion

\subsection{Cointegration Results}

To analyze long run relationship Johansen cointegration procedure has been employed. The results of both trace and max eigen value tests indicated that there was long run equilibrium relationship among variables namely LNGDPPC, LNEXP, LNIMP, LNGCF \&amp; LNLAB. Therefore, the results of both tests confirmed the existence of long run relationship in all the selected countries (Table 6). 


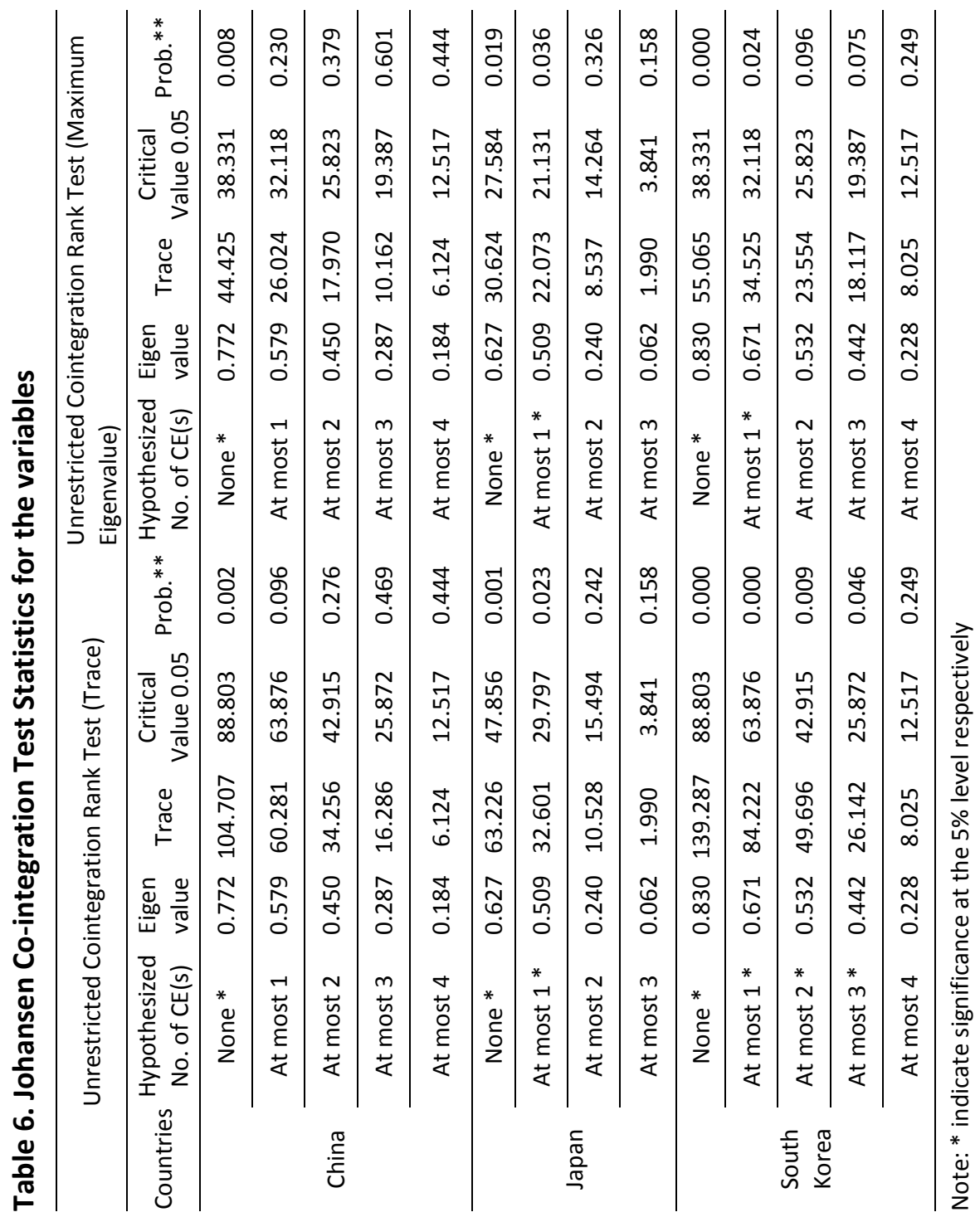

The normalized cointegrating equation for GDP per capita has been given in Table 7. The equation shows that in long run exports affect positively GDP per capita in China. The impact was also significant. Studies like Shirazi and Manap (2005), Aktar (2008), and Husein (2010) also found positive association between exports and economic growth on the basis of normalized cointegrating equations. However, gross capital formation was found to be positive and significant too. Both imports and labour were found to be negative. However, former was significant and later was found to be insignificant in the equation. The equation for Japan indicates that 
imports growth and gross capital formation have positive and significant effect on GDPPC. Although the variable exports hold positive sign but it was found to be insignificant. For South Korea, the normalized cointegrating equation indicated that in the long run all variables except imports have positive and significant impact on GDPPC.

\section{Table 7. Normalized Cointegrating Coefficients for GDPPC Equation}

\begin{tabular}{ccccc}
\hline \multicolumn{5}{c}{ China } \\
\hline LNGDPPC(-1) & LNEXP(-1) & LNIMP(-1) & LNGCF(-1) & LNDLAB(-1) \\
1.000 & $-0.100^{*}(0.058)$ & $0.223^{*}(0.044)$ & $-0.222^{*}(0.065)$ & $0.026(0.024)$ \\
\hline \multicolumn{5}{c}{ Japan } \\
\hline LNGDPPC(-1) & LNEXP(-1) & LNIMP(-1) & LNGCF(-1) \\
1.000 & $-0.059(0.042)$ & $-0.272^{*}(0.032)$ & $-0.311^{*}(0.037)$ & - \\
\hline \multicolumn{5}{c}{ South Korea } \\
\hline LNGDPPC(-1) & LNEXP(-1) & LNIMP(-1) & LNGCF(-1) \\
1.000 & $-0.262^{*}(0.025)$ & $0.093^{*}(0.029)$ & $-0.248^{*}(0.031)$ & $-0.984^{*}(0.140)$ \\
\hline
\end{tabular}

Note: * indicate significance at the $1 \%$ level.

\subsection{VECM Short Run Causality Results}

VECM results comprise the estimate of the speed of adjustment coefficients and short run properties of series. Table 8 reports the short run causality results obtained from VECM. For China, the coefficients of error correction terms (ECT) with GDPPC and exports as dependent variable were negative but former was statistically significant at $5 \%$ level of significance indicating there is convergence from short dynamics towards long run equilibrium. The adjustment coefficient was found to be 0.33 percent implying that speed of adjustment was 33 percent towards long run equilibrium in case of disequilibrium situation. However, short run coefficients of first difference of LNEXP lagged one period for GDP per capita as dependent variable and first difference of LNGDPPC lagged one period for exports equation were found to be statistically insignificant which indicates the absence of short run causality in any direction.

In case of Japan, the results exhibit that coefficient of error correction term (ECT) was not significant in any of two cases for GDPPC and exports. However, the sign was negative (correct) for exports equation. Further, short run coefficient of first difference of LNGDPPC lagged one period for exports equation was found to be positively significant which indicated unidirectional short run causality from GDPPC to exports or growth led exports. The short run coefficient of first difference of LNEXP lagged one period for GDPPC equation was found to be negatively significant. Dummy variable was found to be negative in both cases.

The results for South Korea depicted that coefficient of error correction term was not significant for GDPPC equation however the sign was negative (correct) whereas for exports equation, the error correction term was significant but the sign was positive (incorrect). Thus, the results indicated lack of significant adjustments 
towards long run equilibrium in any disequilibrium situation. Further, short run coefficients of first difference of LNEXP lagged one period for GDPPC equation and first difference of LNGDPPC lagged one period for export equation were negative and insignificant.

Table 8. Short Run Causality Results VECM

\begin{tabular}{|c|c|c|c|c|c|c|}
\hline \multirow[b]{2}{*}{ Variables } & \multicolumn{2}{|c|}{ China } & \multicolumn{2}{|c|}{ Japan } & \multicolumn{2}{|c|}{ South Korea } \\
\hline & $\mathrm{D}$ (LNGDPPC) & $\mathrm{D}$ (LNEXP) & $\mathrm{D}$ (LNGDPPC) & D(LNEXP) & $\mathrm{D}$ (DGDPPC) & $\mathrm{D}$ (LNEXP) \\
\hline \multirow{2}{*}{ ECT } & $-0.330^{*}$ & -0.665 & 0.043 & -0.260 & -0.558 & $1.953 * *$ \\
\hline & $(0.000)$ & $(0.287)$ & $(0.808)$ & $(0.787)$ & $(0.199)$ & $(0.048)$ \\
\hline \multirow{2}{*}{$\mathrm{D}(\mathrm{LNGDPPC})$} & $0.853^{*}$ & 2.714 & $1.191^{* *}$ & $4.681^{* * *}$ & -0.318 & -2.073 \\
\hline & $(0.000)$ & (0.105) & $(0.024)$ & $(0.094)$ & $(0.646)$ & (0.185) \\
\hline \multirow{2}{*}{ D(LNEXP) } & 0.043 & 0.018 & $-0.148^{*}$ & -0.270 & -0.057 & 0.226 \\
\hline & $(0.271)$ & $(0.948)$ & $(0.008)$ & $(0.342)$ & (0.699) & $(0.491)$ \\
\hline \multirow{2}{*}{ D(LNIMP) } & -0.049 & 0.064 & $0.192^{* *}$ & 1.331 & -0.156 & 0.251 \\
\hline & $(0.260)$ & $(0.840)$ & $(0.052)$ & $(0.015)$ & $(0.471)$ & $(0.601)$ \\
\hline \multirow{2}{*}{$\mathrm{D}$ (LNGCF) } & 0.016 & $1.370 * * *$ & $-0.392 * * *$ & $-3.096 * *$ & 0.199 & 0.135 \\
\hline & $(0.871)$ & $(0.075)$ & $(0.084)$ & $(0.014)$ & $(0.444)$ & $(0.813)$ \\
\hline \multirow{2}{*}{$\mathrm{D}(\mathrm{LNLAB})$} & 0.016 & 0.129 & & & 0.010 & 2.313 \\
\hline & $(0.391)$ & $(0.344)$ & - & - & $(0.986)$ & $(0.128)$ \\
\hline DUMMY & & & & & $-0.066 * *$ & $-0.113 * * *$ \\
\hline 1997 & - & - & - & - & $(0.025)$ & $(0.076)$ \\
\hline DUMMY & & & -0.015 & -0.081 & -0.019 & -0.051 \\
\hline 2008 & & - & $(0.156)$ & $(0.164)$ & $(0.238)$ & $(0.172)$ \\
\hline
\end{tabular}

Note: ${ }^{*}, * *$ and ${ }^{* * *}$ indicate significance at the $1 \%, 5 \%$ and $10 \%$ level respectively.

Thus, the results indicated the absence of short run causality between these two variables. Thus results are similar to those reported in the study by Lawrence and Weinstein (1999). Dummy variable for Asian crisis 1997 was found to be negative and statistically significant implying the negative impact of crisis on Korean economy. However, dummy variable for Global crisis 2008 was also found to be negative but statistically insignificant.

Table 9. Summary of Results

\begin{tabular}{lccc}
\hline Country & $\begin{array}{c}\text { Cointegration } \\
\text { Results }\end{array}$ & $\begin{array}{c}\text { VECM Results } \\
\text { (For Short Run Causality) }\end{array}$ & Impact of Dummies \\
\hline China & Cointegrated & No short run causality & - \\
Japan & Cointegrated & GLE & Significant \\
South Korea & Cointegrated & No short run causality & Significant \\
\hline
\end{tabular}

\subsection{Diagnostic Tests}

The models were tested for normality, heteroskedasticity and serial correlation. Diagnostic tests were carried out on the data revealed that models were well specified (Table 10). Diagnostic tests also indicated that the residuals were normally distributed, homoskedastic and serially uncorrelated. However for South Korea, Jarque- Bera normality test depicted non normality. Mcdonald (2014) noted 
that deviation from normality in case of parametric tests is not very sensitive. Wooldridge (2012) pointed out that non- normality of errors is not a serious problem with large sample size. Ghasemi and Zahediasl (2012) also suggested that with large enough sample sizes (> 30 or 40), the violation of the normality assumption should not cause major problems this implies that we can use parametric procedures even when the data are not normally distributed.

Table 10. Results of Diagnostic Tests

\begin{tabular}{lccc}
\hline & China & Japan & South Korea \\
\hline Jarque-Bera Normality Test & $5.870(0.053)$ & $0.312(0.855)$ & $45.049(0.000)$ \\
ARCH Heteroskedasticity Test & $0.030(0.861)$ & $0.290(0.589)$ & $0.032(0.857)$ \\
Breusch-Godfrey LM test & $0.498(0.480)$ & $2.184(0.139)$ & $02.129(0.144)$ \\
\hline
\end{tabular}

Note: $p$-values are reported in parentheses.

\subsection{Impulse response function and variance decomposition analysis results}

The results of impulse response function indicated that among all variable one positive shock to gross capital formation and GDP per capita results in positive response in GDP per capita. In case of exports, one positive shock to imports and gross capital formation brings positive response for exports while positive shock to GDP per capita results in negative response of exports. Variance decomposition analysis (VDA) depicted that GDPPC shock accounted for whole variance of GDPPC in first year. After 10 years, GDP per capita (63.44 percent), imports (28.76 percent), gross capital formation (6.53 percent) and exports (1.10 percent) shocks bring variability in GDP per capita. For exports, in first year exports (81.27 percent) and GDP per capita (18.72 percent) shocks account for variance of exports in case of China. This proportion predicted to change over time as after 10 years, exports (75.80 percent), GDP per capita (8.52 percent), gross capital formation (12.17 percent) and imports (3.28 percent) shocks found to be important source of export variability for China. For Japan, impulse response function indicated one positive shock to GDPPC brings entire positive response of GDPPC. No other variable was found responsible for positive response in GDPPC. Variance decomposition analysis of Japanese GDPPC showed that GDPPC is unexpurgated source of variation in its forecast error. After ten years, variation in GDPPC is accounted for by GDPPC ( 53.58 percent), exports (45.30 percent) and rest of other variables contributed less than one percent. For exports, predominant source of variation are exports (61.47 percent) and GDPPC (38.52 percent). In the tenth year, exports (72.86 percent), imports (10.23 percent), GDPPC (9.58 percent) and gross capital formation (7.31 percent) contributed in exports variability. In case of South Korea, Variance decomposition analysis exhibited GDPPC as predominant source of variation in GDPPC, ranging from 100 percent to 91.11 percent. For exports, GDPPC $(74.20$ percent) and exports (25.79 percent) accounted for export variability. After ten years, exports (58.74 percent), GDPPC (31.11 percent), labour (4.87 percent) and imports (4.34 percent) and gross capital formation (0.92 percent) were the sources of variation in exports (see appendices Table A1, Table A2, and Table A3). 


\section{Conclusion and Policy Implications}

In order to observe the relationship between exports and economic growth for East Asian economies during 1980-2012, this study constructed multivariate framework using the variables GDP per capita, exports, imports, gross capital formation and labour. Time series techniques such as Augmented Dickey-Fuller (ADF) and PhillipsPerron (PP) unit root tests, Johansen cointegration test, vector error correction model (VECM) were employed. The analysis also made use of forecasting techniques namely Impulse Response Function (IRF) and Variance Decomposition Analysis (VDA). The study also conducts diagnostic tests for normality, heteroskedasticity, autocorrelation using Jarque-Bera Normality test, ARCH Heteroskedasticity test and Breusch-Godfrey LM test.

The estimated results suggested that all variables were cointegrated for East Asian economies. The normalized equation shows that in long run exports affects positively GDP per capita in China and South Korea. The impact was also significant. The result exhibits that coefficient of error correction term (ECT) for GDPPC equation was significant only for China indicating significant adjustments towards long run equilibrium in any disequilibrium situation. No short run causality was found between GDPPC and exports in case of China. The short run coefficient of first difference of LNGDPPC lagged one period for exports equation was found to be positively significant for Japan. In case of South Korea, the results indicated the absence of short run causality between these two variables. Hence, export-led growth (ELG) hypothesis was not found valid for China, Japan and South Korea particularly in short run however, reverse causation i.e. growth led exports (GLE) was confirmed for Japan in short run. Thus, the study concluded that export-led growth (ELG) was only long run phenomenon in China and South Korea. The results for Japan supported growth led exports (GLE) particularly for short run. Although East Asian economies export performance remained exceptionally well. But the Asian Financial Crisis 1997 and Global Economic Crisis 2008 resulted in long term adverse effects excluding China.

The results of the study clearly highlight the importance of exports in the selected East Asian economies. In the long run exports are positively affecting GDP per capita in China and South Korea. Hence, these economies should continue to promote their exports. Japan is matured developed economy with high per capita income and has different structure of the economy. Japan has experienced growth led exports in short run and hence this economy will have to promote growth internally as it is suffering from past two decades of stagnation.

The present study gives strong support to the findings of Lin (1999), Yao (2006) for positive effect of exports on economic growth; Liu, Burridge and Sinclair (2002) for long run relationship while study contradicts Liu, Song and Romilly (1997) for short run results and Tsen (2010) who found bidirectional causality for China. For Japan, the study supported Fawson and Chang (1994) while it contradicts Zhang and 
Export Performance and Economic Growth in East Asian Economies -Application of ...

Baimbridge (2011) for causality results. The study partially supported Awokuse (2005) for cointegration results while it contradicts causality results given by Fawson and Chang (1994) and Holman and Graves (1995).

\section{References}

Afzal, M., \& I. Hussain (2010). Export-led Growth Hypothesis: Evidence from Pakistan. Journal of Quantitative Economics, 8(1), 130-147.

Aktar, S. T. i. (2008). An Empirical Examination of the Export-led Growth Hypothesis in Turkey. Journal of Yaşar University, 3(11), 1535-1551.

Awokuse, T. O. (2005). Export-led growth and the Japanese Economy: Evidence from VAR and Directed Acyclic Graphs. Applied Economics Letters, 12(14), 849-858. https://doi.org/10.1080/13504850500358801

Awokuse, T. O. (2005). Exports, Economic Growth and Causality in Korea. Applied Economics Letters, 12(11), 693-696. https://doi.org/10.1080/13504850500188265

Berglee, R (2012). World Regional Geography: People, Places and Globalization. Retrieved from: https://saylordotorg.github.io/text world-regional-geography-people-places-andglobalization/index.html

Boltho, A. (1996). Was Japanese Growth Export-led?. Oxford Economic Papers, 48(3), 415432. https://doi.org/10.1093/oxfordjournals.oep.a028576

Chow, P. C. (2012). Trade and Industrial Development in East Asia: Catching up or Falling Behind.Edward Elgar Publishing. https://doi.org/10.4337/9781849804837

Ding, S., \& J. Knight (2008). Why has China Grown so Fast? The Role of Structural Change. Department of Economics Discussion Paper Series 415, University of Oxford, 1-65.

Engle, R. F., \& Granger, C. W. (1987). Co-integration and Error Correction: Representation, Estimation, and Testing. Econometrica: Journal of the Econometric Society, 251-276. https://doi.org/10.2307/1913236

Evans, O. (2013). Testing Finance-Led, Export-Led and Import-Led Growth Hypotheses on Four Sub-Saharan African Economies .MPRA Paper No. 52460, University Library of Munich, Germany.

Eviews. (2006). Eviews User's Guide (II), (C1994-2007 Quantitative Micro Software.

Fawson, C., \& Chang, T. (1994). Cointegration, Causality, Error-Correction, and Export-Led growth in Six Countries: Japan, Philippines, South Korea, Taiwan, United Kingdom and United States. Economics Research Institute Study Paper, 94(9), 1.

Ghasemi, A., \& Zahediasl, S. (2012). Normality tests for statistical analysis: a guide for nonstatisticians. International journal of endocrinology and metabolism, 10(2), 486-489. https://doi.org/10.5812/ijem.3505

Gujarati, D.N. (1995).Basic Econometrics (3rd ed.), New York, Tata McGraw-Hill.

Hatemi-J, A. (2002). Export Performance and Economic Growth Nexus in Japan: A Bootstrap Approach. Japan and the World Economy, 14(1), 25-33.

Herrerias, M. J., \& Orts, V. (2010). Is the Export-led Growth Hypothesis Enough to Account for China's Growth, China \& World Economy, 18(4), 34-51. https://doi.org/10.1111/j.1749124X.2010.01203.x

Holman J.A., \& Graves P. E. (1995). Korean Exports Economic Growth: An Econometric Reassessment, Journal of Economic Development, 20(2), 45-55. 
Husein, J. (2010). Export-Led Growth Hypothesis in the MENA Region: A Multivariate Cointegration, Causality and Stability Analysis. Applied Econometrics and International Development, 10(2), 161-174.

Johansen, S. (1991).Estimation and Hypothesis Testing of Cointegration Vectors in Gaussian Vector Autoregressive Models. Econometrica: Journal of the Econometric Society, 1551-1580. https://doi.org/10.2307/2938278

Johansen, S. (1995).Likelihood-Based Inference in Cointegrated Vector Autoregressive Models, OUP Catalogue. https://doi.org/10.2307/2938278

Kokko, A. (2002). Export-led Growth In East Asia: Lessons For Europe's Transition Economies, Working Paper No. 142. Retrieved from: http://citeseerx.ist.psu.edu/viewdoc/download?doi=10.1.1.578.8828\&rep=rep1\&type=pdf Kumari, D., \& N. Malhotra (2014). Export- led Growth in India: Cointegration and Causality Analysis. Journal of Economics and Development Studies, 2(2), 297-310.

Kwan, A. C. C., \& Kwok, B. (1995). Exogeneity and the export-led growth hypothesis: the case of China. Southern Economic Journal, 61(4), 1158-1166. https://doi.org/10.2307/1060747

Lawrence, R. Z., \& Weinstein, D. E. (1999). Trade and Growth: Import-led or Export-led? Evidence from Japan and Korea (No. w7264). National Bureau of Economic Research. https://doi.org/10.3386/w7264

Lin, S. (1999). Export Expansion and Economic Growth: Evidence from Chinese Provinces, Pacific Economic Review, 4(1), 65-77. https://doi.org/10.1111/1468-0106.00062

Liu, X., H. Song, \& P. Romilly (1997). An empirical investigation of the causal relationship between openness and economic growth in China. Applied Economics 29(12), 1679-1686. https://doi.org/10.1080/00036849700000043

Liu, X., P. Burridge, \& P.J.N. Sinclair (2010). Relationships between Economic Growth, Foreign Direct Investment and Trade: Evidence from China, Applied Economics, 34(11), 1433-1440. https://doi.org/10.1080/00036840110100835

Mah, J. S. (2007). Economic Growth, Exports and Export Composition in China. Applied Economics Letters, 14(10), 749-752. https://doi.org/10.1080/13504850600592572

Mahadevan, R. \& Suardi, S. (2008). A dynamic analysis of the impact of uncertainty on import-and/or export-led growth: The experience of Japan and the Asian Tigers. Japan and the World Economy, 20(2), 155-174. https://doi.org/10.1016/j.japwor.2006.10.001

Marelli, E. \& M. Signorelli (2011). China and India: Openness, Trade and Effects on Economic Growth. The European Journal of comparative economics, 8(1), 129-154.

McDonald, J.H. (2014). Handbook of Biological Statistics (3rd ed.). Sparky House Publishing, Baltimore, Maryland. pp.133-136 Retrieved from: http://www.biostathandbook.com/normality.html

O'Reilly, B. (2012). Tri-lateral Trade Pact an Asian Game-Changer. Asia Times, dated 23 May 2012, Retrieved from http://www.atimes.com/atimes/China Business/NE23Cb01.html

Page, J. (1994). The East Asian Miracle: Four Lessons for Development Policy. In NBER Macroeconomics Annual 1994, Volume 9 (pp. 219-282). MIT Press. https://doi.org/10.1086/654251

Park, Y. C. \& Patrick, H. (Eds.). (2013). How Finance is Shaping the Economies of China, Japan, and Korea. Columbia University Press. https://doi.org/10.7312/park16526

Phillips, C.B. \& Perron, P. (1988). Testing for a Unit Root in Time Series Regression. Biometrika, 75(2), 335-346. https://doi.org/10.1093/biomet/75.2.335 
Export Performance and Economic Growth in East Asian Economies -Application of ...

Shan, J. \& F. Sun (1998). On the export-led growth hypothesis: the econometric evidence from China. Applied Economics, 30(8), 1055-1065. https://doi.org/10.1080/000368498325228

Shirazi, N. S. \& Manap, T. A. A. (2005). Export-led Growth Hypothesis: Further Econometric Evidence from South Asia. Developing Economies, 43(4), 472-488. https://doi.org/10.1111/j.1746-1049.2005.tb00955.x

Sun, P. \& A. Heshmati (2010). International Trade and its Effect on Economic Growth in China, IZA Discussion Paper No. 5151, 1-38.

Tsen, W. H. (2010). Exports, Domestic Demand and Economic Growth in China: Granger Causality Analysis, Review of Development Economics, 14(3), 625-639. https://doi.org/10.1111/j.1467-9361.2010.00578.x

Wooldridge, J. (2012). Introductory econometrics: A modern approach. Cengage Learning, Nelson Education.

Yao, S. (2006). On Economic Growth, FDI and Exports in China.Applied Economics, 38, 339351. https://doi.org/10.1080/00036840500368730

Yin, F. \& S., Hamori (2012). Economic Openness and Growth in China and India: A Comparative Study, Journal of Reviews on Global Economics, 1, 139-149.

Zang, W. \& Baimbridge, M. (2012). Exports, imports and economic growth in South Korea and Japan: a tale of two economies. Applied Economics 44(3), 361-372. https://doi.org/10.1080/00036846.2010.508722

\section{Appendices}

Table A1. Variance Decomposition Analysis (China)

Variance Decomposition of LNGDPPC:

\begin{tabular}{|c|c|c|c|c|c|}
\hline Period & LNGDPPC & LNEXP & LNIMP & LNGCF & LNDLAB \\
\hline 1 & 100.00 & 0.00 & 0.00 & 0.00 & 0.00 \\
\hline 2 & 94.76 & 0.00 & 4.35 & 0.78 & 0.09 \\
\hline 3 & 85.14 & 0.18 & 11.43 & 3.17 & 0.06 \\
\hline 4 & 76.09 & 0.51 & 18.35 & 4.97 & 0.06 \\
\hline 5 & 69.90 & 0.79 & 23.28 & 5.90 & 0.10 \\
\hline 6 & 66.42 & 0.96 & 26.14 & 6.32 & 0.14 \\
\hline 7 & 64.77 & 1.05 & 27.55 & 6.46 & 0.15 \\
\hline 8 & 64.11 & 1.08 & 28.15 & 6.48 & 0.15 \\
\hline 9 & 63.78 & 1.09 & 28.46 & 6.49 & 0.15 \\
\hline 10 & 63.44 & 1.10 & 28.76 & 6.53 & 0.14 \\
\hline Variance Decomposition of LNEXP: & & & LNGCF & LNDLAB \\
\hline Period & LNGDPPC & LNEXP & LNIMP & 0.00 & 0.00 \\
\hline 1 & 18.72 & 81.27 & 0.00 & 7.74 & 0.76 \\
\hline 2 & 10.42 & 77.47 & 3.59 & 11.10 & 0.53 \\
\hline 3 & 7.28 & 77.51 & 3.56 & 12.39 & 0.42 \\
\hline 4 & 5.90 & 78.32 & 2.95 & 13.29 & 0.35 \\
\hline 5 & 6.18 & 77.63 & 2.53 & 13.36 & 0.32 \\
\hline 6 & 7.32 & 76.58 & 2.39 & 12.99 & 0.29 \\
\hline 7 & 8.17 & 75.98 & 2.55 & 12.60 & 0.26 \\
\hline 8 & 8.53 & 75.75 & 2.84 & 12.32 & 0.24 \\
\hline 9 & 8.57 & 75.73 & 3.11 & 12.17 & 0.22 \\
\hline 10 & 8.52 & 75.80 & 3.28 & & \\
\hline
\end{tabular}


Neena MALHOTRA \& Deepika KUMARI

Table A2. Variance Decomposition Analysis (Japan)

\begin{tabular}{|c|c|c|c|c|}
\hline \multicolumn{5}{|c|}{ Variance Decomposition of LNGDPPC: } \\
\hline Period & LNGDPPC & LNEXP & LNIMP & LNGCF \\
\hline 1 & 100.00 & 0.00 & 0.00 & 0.00 \\
\hline 2 & 86.40 & 8.59 & 1.90 & 3.10 \\
\hline 3 & 72.70 & 23.47 & 1.40 & 2.42 \\
\hline 4 & 66.76 & 30.79 & 0.86 & 1.57 \\
\hline 5 & 63.18 & 35.00 & 0.63 & 1.17 \\
\hline 6 & 59.85 & 38.64 & 0.54 & 0.96 \\
\hline 7 & 57.37 & 41.28 & 0.53 & 0.79 \\
\hline 8 & 55.75 & 43.01 & 0.54 & 0.67 \\
\hline 9 & 54.55 & 44.29 & 0.55 & 0.59 \\
\hline 10 & 53.58 & 45.30 & 0.56 & 0.53 \\
\hline \multicolumn{5}{|c|}{ Variance Decomposition of LNEXP: } \\
\hline Period & LNGDPPC & LNEXP & LNIMP & LNGCF \\
\hline 1 & 38.52 & 61.47 & 0.00 & 0.00 \\
\hline 2 & 24.90 & 63.52 & 4.75 & 6.82 \\
\hline 3 & 19.32 & 64.40 & 7.65 & 8.61 \\
\hline 4 & 16.70 & 67.12 & 8.34 & 7.82 \\
\hline 5 & 14.69 & 69.01 & 8.83 & 7.45 \\
\hline 6 & 12.98 & 70.04 & 9.41 & 7.54 \\
\hline 7 & 11.77 & 70.96 & 9.74 & 7.51 \\
\hline 8 & 10.89 & 71.77 & 9.92 & 7.40 \\
\hline 9 & 10.17 & 72.38 & 10.08 & 7.35 \\
\hline 10 & 9.58 & 72.86 & 10.23 & 7.31 \\
\hline
\end{tabular}

Table A3. Variance Decomposition Analysis (South Korea)

\begin{tabular}{|c|c|c|c|c|c|}
\hline \multicolumn{6}{|l|}{ Variance Decomposition of LNGDPPC: } \\
\hline Period & LNGDPPC & LNEXP & LNIMP & LNGCF & LNLAB \\
\hline 1 & 100.00 & 0.00 & 0.00 & 0.00 & 0.00 \\
\hline 2 & 95.01 & 3.04 & 0.19 & 0.93 & 0.80 \\
\hline 3 & 95.18 & 2.19 & 0.55 & 0.81 & 1.25 \\
\hline 4 & 94.16 & 1.70 & 1.43 & 0.63 & 2.06 \\
\hline 5 & 93.14 & 1.47 & 2.29 & 0.51 & 2.56 \\
\hline 6 & 92.48 & 1.30 & 2.88 & 0.44 & 2.87 \\
\hline 7 & 92.04 & 1.17 & 3.29 & 0.38 & 3.10 \\
\hline 8 & 91.68 & 1.08 & 3.60 & 0.33 & 3.28 \\
\hline 9 & 91.36 & 1.01 & 3.87 & 0.30 & 3.43 \\
\hline 10 & 91.11 & 0.96 & 4.08 & 0.27 & 3.55 \\
\hline Variance Decomposition of LNEXP: & LNEXP & LNIMP & LNGCF & LNLAB \\
\hline Period & LNGDPPC & 74.20 & 0.00 & 0.00 & 0.00 \\
\hline 1 & 25.79 & 75.17 & 1.00 & 1.15 & 0.07 \\
\hline 2 & 22.59 & 73.58 & 0.75 & 1.40 & 0.74 \\
\hline 3 & 23.50 & 70.03 & 1.30 & 1.20 & 1.91 \\
\hline 4 & 25.54 & 66.67 & 2.23 & 1.15 & 2.81 \\
\hline 5 & 27.11 & 64.33 & 2.87 & 1.10 & 3.38 \\
\hline 6 & 28.29 & 62.62 & 3.30 & 1.03 & 3.82 \\
\hline 7 & 29.20 & 61.15 & 3.68 & 0.98 & 4.22 \\
\hline 8 & 29.95 & 59.85 & 4.03 & 0.95 & 4.57 \\
\hline 9 & 30.58 & 58.74 & 4.34 & 0.92 & 4.87 \\
\hline 10 & 31.11 & & &
\end{tabular}

